Bangl. J. Vet. Med. (2009). 7(2) : $314-319$

\title{
ROTAVIRUS INFECTION IN HUMAN AND BIRDS
}

\author{
M. S. Islam ${ }^{1}$, M. M. Alam ${ }^{1}$, M. M. Rahman ${ }^{2}$ and M. U. Ahmed ${ }^{1}$ \\ ${ }^{1}$ Department of Medicine, Faculty of Veterinary Science, Bangladesh Agricultural University, Mymensingh-2202, \\ Bangladesh, ${ }^{2}$ Laboratory Medicine, Islami Bank Hospital, Motijhil, Dhaka, Bangladesh
}

\begin{abstract}
An epidemiological study on rotavirus infection using 315 stool specimens from hospitalized diarrhoeic human patients and 251 fecal specimens from diarrheic birds (broiler) wear examined by RNA polyacrylamide-gel electrophoresis and silver staining (PAGE-SS) technique. Rotavirus was detected in 35.28\% (111/315) stool specimens. The highest rate of rotavirus infection in human was detected in the winter (45.94\%), particularly in the month of December to January $(44 \%-51 \%)$. The rotavirus diarrhea was found slightly higher in male (35.97\%) than female (34.12\%). Rotavirus was detected in $13.15 \%$ (33/251) birds' fecal specimens. The birds were affected by the rotavirus, showing only the long RNA electropherotype. The antigenic studies with reference to subgroups and serotypes specificity and its zoonotic potential needs to be studied further.
\end{abstract}

Key words: Human rotavirus, avian rotavirus, polyacrylamide-gel electrophoresis, electropherotypes

\section{INTRODUCTION}

Rotavirus gastroenteritis is a worldwide disease affecting primarily infants, young children and the young of a wide variety of mammalian and avian species (Estes et al., 1983). Rotaviruses assume a special importance as etiologic agent of severe diarrhoeal illness in developing countries where malnutrition is common in young animals and children, and severe dehydration following rotavirus diarrhoea leads to a high rate of mortality (Black et al., 1982). Human group-A rotavirus is the most important cause of severe diarrhoea in children worldwide (Cook et al., 1990; Kapikin and Chanock, 1990) and rotavirus infection is associated with extensive morbidity and mortality in Bangladeshi children.

As in mammals, rotavirus infection in avian species is frequently associated with outbreaks of diarrhea. The economic significance of rotaviral enteritis to the poultry industry has not yet been defined, but by analogy with the situation in mammals it is likely to be significant. Avian rotavirus were first observed in faeces of young turkey poults with diarrhoea and enteritis in South Dakota (Bergeland et al., 1977) and subsequently were detected in the intestinal contents of diarrhoeic turkey poults in Northern Ireland (McNulty, 1978) and in the faeces of diarrhoeic commercial laying hens in England (Jones, et al., 1979). An antigenically distinct rotavirus has been isolated from chickens in Northern Ireland (McNulty et al., 1981) and has been designated as the pherototype member for the group D rotaviruses (Pedley et al., 1986). Rotavirus in birds belongs to groups A, D, F and G (Saif, 1989).

The rotaviruses belonging to the family Reoviridae contain a genome of 11 segments of double stranded RNA (dsRNA) which can be separated into distinct bands by electrophoresis (Estes et al., 1984). Electropherotyping (the migration pattern of the 11 genome segments following electrophoresis) of rotaviruses RNA became an important laboratory and epidemiologic technique for identification and characterization of rotavirus as well as its strains (Rodger et al., 1981) because, this marker is both characteristic and constant for a given virus strain (Steele and Alexander, 1987 and Estes et al., 1984).

Detail studies on the epidemiology of rotavirus associated diarrhoea in human and birds have been performed in advanced countries. In Bangladesh very limited works have been done in this context. Recently avian rotavirus like virus was detected in Bangladesh. The number of detection was very low approximately $0.86 \%$ in 232 broiler chicks (Ahmed et al., 2006). This result raised a question whether avian rotaviruses do exist at all in Bangladesh. Since sample size was small and detection was too low, we felt necessity to substantiate this finding whether avian rotavirus is responsible for enteritis in chickens and electrophoretic identification of prevailing rotavirus strains in different regions of Bangladesh has not yet been performed. Considering the importance of rotavirus associated diarrhoea, its diverse epidemiological features and for rapid detection of rotavirus infection in human and birds have been studied in this present research. 


\section{S. Islam and others}

\section{MATERIALS AND METHODS}

A total of 251 faecal specimens were collected from "Tania" poultry farm, "Jalil" poultry farm, "Babul" poultry farm, the neighboring village poultry farm of BAU Campus, Mymensingh; "Petrol pump" poultry farm, Babuganj, Barisal; "Shaikat" poultry farm, Pazulia, Gazipur and "Pahartauli" poultry farm, Chittagong and 315 stool specimens (189 male and 126 female) were collected from two hospitals namely S. K. Hospital and Mymensingh Medical College Hospital (MMCH), Mymensingh during the period from July 2006 to May 2007. The faecal specimens were obtained from the cloaca in case of broiler birds and freshly voided stool specimens were collected during defecation in sterile screw capped container. The date of collection, age, sex, clinical signs, important clinical history and environmental situations were recorded in each case using pre-tested questioners.

The faecal specimens were examined for rotavirus by electrophoresis. Viral RNA from stool specimens was extracted as described by Seele and Alexander (1978) and Dimitrov et al. (1984). Electropherotyping of viral RNA was carried out in $10 \%$ polyacrylamide slab gels, and silver staining technique as described by Kobayashi et al. (1989).

\section{Statistical analysis}

Statistical analyses were performed using the chi-square test and Fisher's exact test. The level of significance was set at $\mathrm{p}<0.05$.

\section{RESULTS AND DISCUSSION}

Of 315 stool samples of human tested by polyacrylamide gel electrophoresis, $111(35.28 \%)$ yielded a typical rotavirus electrophoretic pattern (Fig. 1). Month-wise prevalence of rotavirus infection in diarrhoeic human patients is shown in Table 1. The prevalence rate of rotavirus infection in July, December, January, February, March were $7.5 \%, 44 \%, 51.30 \%, 36.84 \%$ and $11.32 \%$ respectively. The highest prevalence was recorded in January $(51.30 \%)$ and the lowest in July $(7.50 \%)$. The association of human rotavirus infection in diarrhoea in different seasons revealed that in rainy season (July-October) $7.5 \%$ (3 of 40) specimens, in winter season (November-February) 45.94\% (102 of 222) and specimens in summer season 11.32\% (6 of 53), diarrhoeic specimens showed a characteristic electrophoretic mobility of dsRNA of rotavirus on PAGE (Table 2 ). The incidence of rotavirus infection in diarrhoea was slightly higher in male than those of female. Of 189 specimens from male patients $68(35.97 \%)$ were positive for rotavirus infection while $43(34.12 \%)$ of 126 specimens from female revealed the presence of rotavirus. The seasonal variation of rotavirus association with diarrhoea in male and female patient has shown in Table 3. 6.45\%, 47.07\% and 9.09\% male patients were infected with rotavirus infection in rainy, winter and summer seasons respectively and $11.11 \%, 44.18$ and $12.90 \%$ female patients were infected with rotavirus infection in rainy, winter and summer seasons respectively.

Table 1. Month-wise prevalence of rotavirus infection in human and birds detected by polyacrylamide gel electrophoresis and silver staining technique

\begin{tabular}{|c|c|c|c|c|c|c|c|}
\hline \multicolumn{4}{|l|}{ Human } & \multicolumn{4}{|l|}{ Birds } \\
\hline \multirow[t]{2}{*}{ Months } & \multirow[t]{2}{*}{ No. tested } & \multicolumn{2}{|c|}{ Positive } & \multirow[t]{2}{*}{ Months } & \multirow[t]{2}{*}{ No. tested } & \multicolumn{2}{|c|}{ Positive } \\
\hline & & No. & $\%$ & & & No. & $\%$ \\
\hline July & 40 & 03 & 7.50 & August & 20 & 0 & 0.00 \\
\hline December & 50 & 22 & 44.00 & January & 40 & 0 & 0.00 \\
\hline January & 115 & 59 & 51.30 & February & 60 & 5 & 8.34 \\
\hline February & 57 & 21 & 36.84 & March & 131 & 28 & 21.37 \\
\hline March & 53 & 06 & 11.32 & & & & \\
\hline Total & 315 & 111 & 35.28 & & 251 & 33 & 13.15 \\
\hline
\end{tabular}

During the 10 months study period of rotaviral diarrhoea in birds, a total of 251 faecal specimens examined by PAGE. Of these $33(13.15 \%)$ specimens showed a characteristics electropherotypic mobility of dsRNA of rotavirus (Fig. 2). The migration pattern of all dsRNA detected positive rotaviruses were similar in gel electrophoresis and their migration speed was same as previously designated avian rotavirus group D. 
Table 2. Season-wise prevalence of rotavirus diarrhoea in human and birds

\begin{tabular}{|c|c|c|c|c|c|c|}
\hline \multirow{3}{*}{ Seasons } & \multicolumn{3}{|l|}{ Human } & \multicolumn{3}{|l|}{ Birds } \\
\hline & \multirow[t]{2}{*}{ No. tested } & \multicolumn{2}{|c|}{ Positive } & \multirow[t]{2}{*}{ No. tested } & \multicolumn{2}{|c|}{ Positive } \\
\hline & & No. & $\%$ & & No. & $\%$ \\
\hline Rainy (July-October) & 40 & 03 & 7.50 & 20 & 0 & 0.00 \\
\hline $\begin{array}{l}\text { Winter (November- } \\
\text { February) }\end{array}$ & 222 & 102 & 45.94 & 100 & 05 & 5.00 \\
\hline Summer (March-June) & 53 & 06 & 11.32 & 131 & 28 & 21.37 \\
\hline Total & 315 & 111 & 35.28 & 251 & 33 & 13.15 \\
\hline
\end{tabular}

Table 3. Sex and season-wise prevalence of rotavirus diarrhoea in human

\begin{tabular}{|c|c|c|c|c|c|c|}
\hline \multirow{3}{*}{ Seasons } & \multicolumn{3}{|l|}{ Male } & \multicolumn{3}{|l|}{ Female } \\
\hline & \multirow[t]{2}{*}{ No. tested } & \multicolumn{2}{|c|}{ Positive } & \multirow[t]{2}{*}{ No. tested } & \multicolumn{2}{|c|}{ Positive } \\
\hline & & No. & $\%$ & & No. & $\%$ \\
\hline Rainy (July-October) & 31 & 02 & 6.45 & 09 & 01 & 11.11 \\
\hline $\begin{array}{l}\text { Winter (November- } \\
\text { February) }\end{array}$ & 136 & 64 & 47.07 & 86 & 38 & 44.18 \\
\hline Summer (March-June) & 22 & 02 & 9.09 & 31 & 04 & 12.90 \\
\hline Total & 189 & 68 & 35.97 & 126 & 43 & 34.12 \\
\hline
\end{tabular}

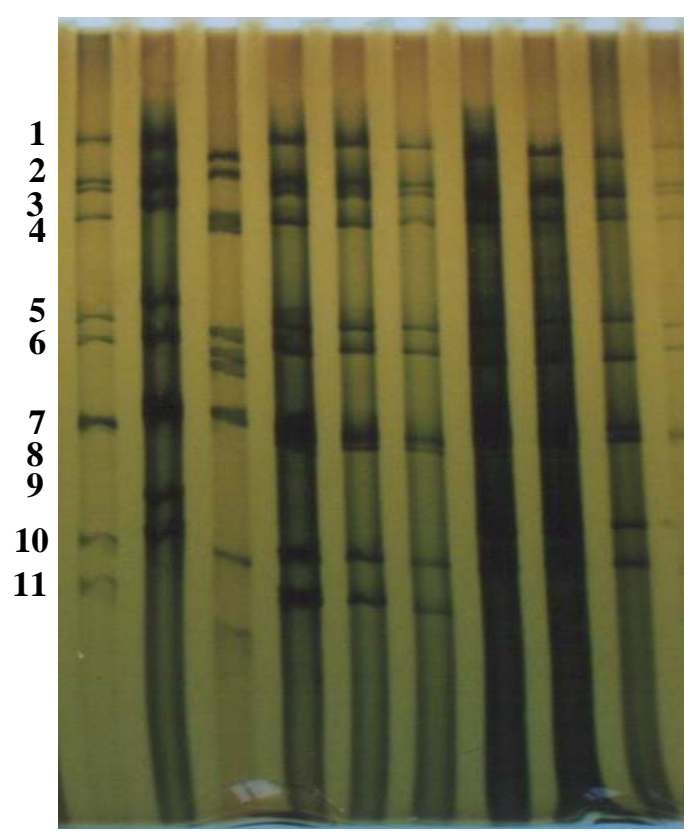

Fig. 1. Electrophoretic migration pattern of human rotavirus ds RNA in polyacrylamide gel. In the left side 1-11 numbers are indicated the ds RNA segment.

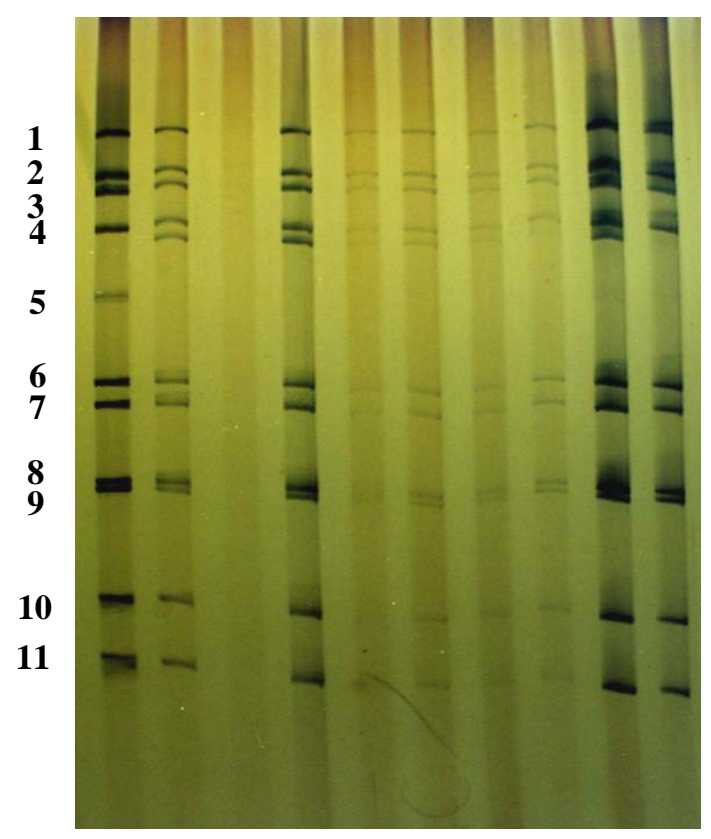

Fig. 2. Electrophoretic migration pattern of avian rotavirus ds RNA in polyacrylamide gel. In the left side 1-11 numbers are indicated the ds RNA segment. 


\section{S. Islam and others}

Rotavirus infection was found among diarrhoeic birds in the months of August, January, February and March were $0 \%(0 / 20), 0 \%(0 / 40), 8.34 \%(5 / 60)$ and $21.37 \%(28 / 131)$, respectively (Table 1$)$. The highest prevalence was recorded in March (21.37\%). In this study the higher prevalence rate of rotavirus infection in human was recorded during the month of December to January ( $44.00 \%$ to $51.30 \%$ ) as compared to $7.50 \%$ to $36.84 \%$ during July to February. There was significant difference between month and rotavirus infection $(\mathrm{p}<0.0001)$. The predominance of rotavirus infection was observed in the month of December and January which is in agreement with the findings of Chan et al. (1998).

A seasonal pattern of rotavirus disease has been reported in many part of the world. Higher prevalence of rotavirus gastroenteritis in cool dry season has been described in tropical regions as well as in temperate zones (Anseri et al., 1991). These findings also correlate with our present study in case human (45.94\%). Black et al. (1982) described in their longitudinal studies of diarrhoeal diseases Bangladeshi children that the incidence of rotavirus diarrhoea did not show marked seasonal variation, except for a small peak in December. But in our study, there was marked variation and was statistically significant $(p<0.0001)$. This was due to in rainy and summer season small no. of specimens were tested and among them maximum were collected from adult (usually the prevalence rate of rotavirus infection in adult is 5\%, Echeverria et al. (1983). Although the reasons for the seasonality of rotavirus infection have not been well clarified, it has been suggested that cooler months could prolong the survival of rotavirus and accordingly contribute to their spread. Furthermore, lower humidity may also promote the generation of virus-laden dust, which mediates transmission of viruses. The survival of rotaviruses is favoured by a relative humidity of $\leq 50 \%$ (Anseri et al., 1991).

In relation to study on seasonal variation, the prevalence rates in male were $6.45 \%$ in rainy, $47.05 \%$ in winter and $9.09 \%$ in summer season whereas, in female $11.11 \%, 44.70 \%$, and $12.90 \%$ were found positive for rotavirus respectively. In the present study it was observed that percentage of rotavirus associated diarrhoea was slightly higher in male (35.97\%) than the female (34.12\%) patients. In our study there was no statistically significant of rotavirus infection between male and female $(\mathrm{p}<0.736)$. These findings are in conformity with the earlier report of Samarbafzadeh et al. (2005) and Talukder (1999). Ryan et al. (1996) also reported a higher prevalence of rotavirus associated diarrhoea in male $(56 \%)$ than in female $(44 \%)$.

The main clinical symptoms of patients as revealed by examination of patient records were diarrhoea, vomiting, fever, and abdominal pain. The frequency of each symptom seemed not to differ appreciably between the pediatric and adult patient groups studied. The duration and severity of each clinical symptom also did not differ significantly between the two age groups. Thus, although it has been reported that adult rotavirus infections are usually clinically mild (Kapikian and Chanock, 1990), the symptoms were equally severe in both children and adults in our study as far as hospitalized patients were concerned.

This study recorded the higher rate of rotavirus infection in birds in the month of March $21.37 \%$ and higher prevalence of rotavirus infection gastroenteritis in summer season $(21.37 \%)$. The month-wise difference of rotavirus infection in birds was statistically significant (Fisher's exact test $<0.0001$ ) and season-wise difference was also statistically significant (Fisher's exact test $<0.0001$ ). Although, in temperate climates, a definite peak of diseases occurs during the winter months but infection do occur throughout the year in temperate, tropical and subtropical climates (Estes et al., 1984). It is still possible that virus-associated factors, such as virulence, as previously established in mammalian rotaviruses caused by genetic reassortment events (Estes, 1996), as well as host associated factors, such as natural resistance to rotavirus due to different genetic poultry lines. In addition, predisposing factors, such as diseases attributed to other pathogens like coronaviruses, reoviruses, enterovirus, and adenovirus (Dea and Tijssen, 1988); physiological stress; and toxic and environmental factors, such as temperature, ventilation, and husbandry, may directly interfere in the resolution of the disease after rotavirus infection (Villarreal et al.,2006) . However, the importance of the result of higher prevalence in the month of March (summer season) $21.37 \%$ in birds is that they may constantly shedding the virus and disseminate the virus to susceptible chickens. Further investigations are required in this regard. In India a research was conducted where the prevalence of avian rotaviruses in diarrheic (n-46) and environmental (n-31) samples was $17.39 \%(8 / 46)$ and $3.22 \%(1 / 31)$ respectively (Savita et al., 2008). In this study a high frequency of rotavirus in birds was found using PAGE, indicating that this virus, although neglected as an important putative pathogen of poultry, may have a role in the pathogenesis of enteric disease of layers and broilers. 
The main clinical signs of birds as revealed, by examination of bird records were diarrhea, gasping, and rales. It was observed that diarrhoeic symptoms was initiated at first days of age and remained in some birds up to marketing (35 days). In one farm, suddenly 13 birds (out of 400 birds) were died during the peak time of diarrhoeic symptom at the age of 12 days but it is not sure whether the mortality was due to rotavirus or other pathogens. Although in birds the morbidity is high due to rotaviral infection but mortality varies from 4 to $7 \%$ on the basis of severity (McNulty et al., 1978). Further studies are needed in order to asses the real impact of rotavirus in birds in Bangladesh such as those focused on the genetic diversity of the detected strains and the effects after experimental inoculation of birds.

From the present study, it may be concluded that rotavirus infection is present throughout the year in Bangladesh, the occurrence is very low in very young and older man and animals. Rotavirus infections are much higher in human than birds.

The present study showed some epidemiological parameters of rotavirus infection in man and birds (broiler). However, further epidemiological studies in relation to the strains of virus, antigenic structures with reference to serotypes and zoonotic potential of rotavirus is necessary before introduction of vaccines against rotavirus diarrhea in Bangladesh.

\section{REFERENCES}

1. Anseri SA, Springthorpe VS and Sattar SA (1991). Survival and vehicular spread of human rotavirus: Possible relation to seasonality of out breaks. Revews of Infecious Disease 13 (3): 448-461.

2. Ahmed MS and Ahmed MU (2006). Detection of avian rotavirus like virus in Bangladesh. Bangladesh Journal of Veterinary Medicine 4 (2): 73-77.

3. Bergeland ME, McAdaragh JP and Stotz I (1977). Rotaviral enteritis in turkey poults. Proc. 26 $6^{\text {th }}$ Western Poultry. Disease. Conference Temp,Ariz. pp. 129-130.

4. Black RE, Brown KH, Becker S, Alim ARMA and Huq I (1982). Longitudinal studies of infections diseases and physical growth of children in rural Bangladesh. II. Incidence of diarrhoea and association with known pathogens. American Journal of Epidemiology 115: 305-314.

5. Chan PKS, Tam JS, Nelsm EAS, Fung KSC, Adeyemi-Doro RAB, Fok TF and cheng AF (1998). Rotavirus infection in Honk Kong: epidemiology and estimates of disease burden. Epidemiology and Infection 120: 321-325.

6. Cook SMI, Glass CW, Lebaron and Ho MS (1990). Global seasonality of rotavirus infections. Bulletin of WHO 68: 171177.

7. Dea S and Tijssen P (1988). Agents associated with outbreaks of diarrhoea in turkey flocks in Quebec. Canadian Journal of Veterinary Research 52: 53-57.

8. Dimitrov DH, Graham DY, Lopez J, Muchinik G, Velasco G, Stentback WA and Estes MK (1984). RNA electropherotypes of human rotavirus from North and South America. Bulletin of WHO 62 (2): 321-329.

9. Echeverria P, Blacklow NR, Cukor GG, Vibulbandhitkit S, Changchawalit S and Boonthai P (1983). Rotavirus as a cause of severe gastroenteritis in adults. Journal of Clinical Microbiology 18 (3): 663-667.

10. Estes MK (1996). Rotaviruses and their replication In: Fields NB, Knipe MD and Howley PM (eds), Fields Virology. $3^{\text {rd }}$ edn., Philadelphia, Lippincett-Raven. pp. 1625-55.

11. Estes MK, Palmer EL and Obijeski JF (1983). Rotaviruses: a review. Current Topics in Microbiology and Immunology 105: $123-184$

12. Jones RC, Hughes CS and Henry RR (1979). Rotavirus infection in commercial laying hens. Veterinary Record 104: 22.

13. Kapikian AZ and Chanock RM (1990). Rotaviruses. In: Fields BN, Knipe DM, Chanock M, Hirsch MS, Melnick JL, Monath TP and Roizman, B (eds). Fields Virology 2: 1353-1404.

14. Kobayashi N, Lintag IC and Urasawa T, Tangiguchi K, Saniel MC and Urasawa S (1989). Unusual human rotavirus strains having subgroup 1 specificity and long RNA electrophoerotype. Archives of Virology 109: 11-23.

15. Estes MK, David Y, Graham, Dimitre H and Dimitrov (1984). The molecular epidemiology of rotavirus gastroenteritis. Progress in Medical Virology 29: 1-22.

16. McNulty MS, Allan GM and Stuart JC (1978). Rotavirus infection in avian species. Veterinary Record 103: 319-320.

17. McNulty MS, Allan GM, Todd D, McFerrran JB and McCracken RM (1981). Isolation from chicken of a rotavirus lacking the rotavirus group antigen. Journal of General Virology 55: 405-413.

18. Pedley S, Bridger JC, Chasey D and McCrac,MA (1986). Definition of two new groups of atypical rotaviruses. Journal of General Virology 67: 131-137. 


\section{S. Islam and others}

19. Rodger SM, Bishop RF, Birch C, McLean B and Holmes IH (1981). Molecular epidemiology of human rotaviruses in Melbourne, Australia, from 1973 to 1979 , as determined by electrophoresis of genome ribonucleic acid. Journal of Clinical Microbiology 13 (2): 272-278.

20. Ryan MJ, Ramsay M, Brown D, Gay NJ, Farrington CP and Wall PG (1996). Hospital admissions attributable to rotavirus infection in England and Wales. Journal of Infectious Diseases 174 (Suppl): S 12-18.

21. Saif LJ (1989). Immunodiagnosis of enteric viral infections application of electron microscopy and monoclonal antibodies. Proc. $38^{\text {th }}$ Western Poultry Disease Conference, Tempe, Ariz. pp. 232-237.

22. Samarbafzadeh A, Tehrani EM, Makvandi M and Taremi, M (2005). Epidemiological aspects of rotavirus infection in Ahwaz, Iran. Journal of Health, Population and Nutrition 23 (3): 245-249.

23. Savita Al, Kusumakar Malik YPS, Prashad MG (2008). Indian Journal of Biotechnology 7: 554-556.

24. Steele AD and Alexandar, JJ (1987). Molecular epidemiology of rotavirus in black infants in South Africa. Journal of Clinical Microbiology 25 (12): 2384-2387.

25. Talukder MRI (1999). Rotavirus diarrhoea in human and animals in Mymensingh. Thesis MS (Vet. Sci.) in Medicine, Department of Medicine Bangladesh Agricultural University, Mymensingh, Mymensingh.

26. Villarreal LYB, Uliana G, Valenzuela C, Chacon JLV, Saidenberg ABS, Sandches AA, Brandao PE, Jerez JA and Ferreira AJP (2006). Rotavirus detection and isolation from chickens with or without symptoms .Brazilian Journal of Poultry Science 8 (3): 187-191. 